\title{
Tuberculosis reactivation during novel, biologic therapy
}

\author{
Cristina Popescu ${ }^{1,2^{*}}$, Violeta Molagic ${ }^{1}$, Cătălin Tilişcan ${ }^{1,2}$, Ruxandra Moroti ${ }^{1,2}$, Adriana Hristea ${ }^{1,2}$, Mihaela Rădulescu ${ }^{1,2}$,

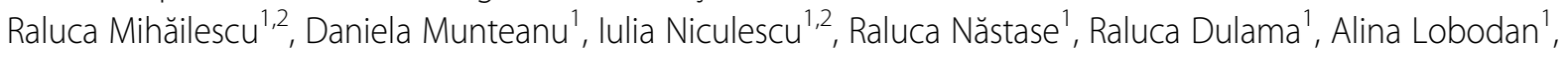 \\ Raluca Hrişcă', Raluca Jipa', Anca-Ruxandra Negru', Irina Lăpădat ${ }^{1}$, Roxana Petre', Mircea Chiotan' , \\ Cornel Camburu', Viorica Poghirc', Raluca Popescu', Victoria Aramă1,2
}

From The 9th Edition of the Scientific Days of the National Institute for Infectious Diseases Prof Dr Matei Bals Bucharest, Romania. 23-25 October 2013

\section{Background}

Biologic immunotherapy such as anti-TNF or monoclonal antibody against $\mathrm{CD} 20$ protein revolutionized the treatment of autoimmune diseases. Unfortunately, the patients receiving this therapy are at higher risk for bacterial or fungal infections, and at risk for reactivation of latent viral infections and latent tuberculosis. We present a series of patients receiving biologic therapy, admitted in the Adults 3 Department of the National Institute for Infectious Diseases "Prof. Dr. Matei Balş" for prolonged fever.

\section{Case report}

All of the patients were diagnosed with tuberculosis. One patient was treated with rituximab for non-Hodgkin lymphoma, 2 patients were treated with infliximab for rheumatoid arthritis, one patient was treated with infliximab for ankylosing spondylitis and one patient was treated with etanercept for severe psoriasis. Two of the patients were diagnosed with pulmonary tuberculosis and for three patients the localization of tuberculosis was not identified. All of the patients had quantiferon TB gold positive. Only one of the patients had positive microbiologic tests for tuberculosis. All of the patients had a good therapeutic response after anti-tuberculous therapy. None of the patients had been tested for latent tuberculosis prior to initiation of biologic therapy.

\section{Conclusion}

We emphasize the importance of anti-tuberculosis prophylaxis for patients diagnosed with latent tuberculosis,

\footnotetext{
* Correspondence: crispopescu3@yahoo.com

${ }^{1}$ National Institute for Infectious Diseases "Prof. Dr. Matei Balş", Bucharest, Romania
}

Full list of author information is available at the end of the article before the start of biologic therapy. The diagnosis of latent tuberculosis remains an important issue especially in a country with high incidence of tuberculosis.

\section{Authors' details}

"National Institute for Infectious Diseases "Prof. Dr. Matei Balş", Bucharest, Romania. ${ }^{2}$ Carol Davila University of Medicine and Pharmacy, Bucharest, Romania.

Published: 16 December 2013

doi:10.1186/1471-2334-13-S1-O25

Cite this article as: Popescu et al:: Tuberculosis reactivation during novel, biologic therapy. BMC Infectious Diseases 2013 13(Suppl 1):O25.
Submit your next manuscript to BioMed Central and take full advantage of:

- Convenient online submission

- Thorough peer review

- No space constraints or color figure charges

- Immediate publication on acceptance

- Inclusion in PubMed, CAS, Scopus and Google Scholar

- Research which is freely available for redistribution

Submit your manuscript at www.biomedcentral.com/submit
C Bïomed Central
C Biomed Central

(c) 2013 Popescu et al; licensee BioMed Central Ltd. This is an Open Access article distributed under the terms of the Creative Commons Attribution License (http://creativecommons.org/licenses/by/2.0), which permits unrestricted use, distribution, and reproduction in any medium, provided the original work is properly cited. 